\title{
Payment Systems Are Different: Shouldn't Their Regulation Be Too?
}

\author{
JOHN SIMON *
}

Reserve Bank of Australia

\begin{abstract}
This paper makes the case that the structure of payment systems is such that, in contrast to competition in normal markets, private incentives can encourage activities and pricing that do not necessarily improve social welfare. Furthermore, while there is usually a reasonable presumption that where arrangements do not breach antitrust laws they are efficient, this presumption does not necessarily carry over to payment systems. Thus, there is a case for the regulation of payment systems. In particular, the paper suggests that, because of the distinctive nature of payment systems, payment system specific regulation has a number of advantages over generic antitrust regulation.
\end{abstract}

\section{Introduction}

Payment systems are different from normal markets. They are characterised by network effects, joint supply and joint demand, and normal competitive forces do not always operate. These characteristics mean that conclusions about the effects of particular conduct on competition and efficiency may be different from those that are reached in other markets. For example, cooperation between competitors, something that is normally viewed as detrimental to competition, has the potential to enhance economic efficiency in payment systems. At the same time, competition between payment systems can sometimes perversely push fees in the competing systems up, not down. And this can occur even if costs are falling - something that would be unlikely to occur in most other markets. By their very nature, these characteristics mean that the operation of normal market forces may not lead to socially optimal outcomes as could be expected in most other markets.

Given this assessment, there is a case for regulatory action. Such action can be taken either under generic competition law or through payment system specific regulation. This paper argues that, because of the complexity and distinctiveness of payment systems, specific legislation emphasising efficiency may be better suited to the task than existing generic antitrust laws.

The paper has three parts. The first advances the main analytical proposition of the paper: payment systems are different from normal markets. The second considers the implications of this proposition for two different regulatory approaches. The third section discusses the reforms that have been implemented in Australia under its payment system specific

\footnotetext{
* Economic Analysis Department, Reserve Bank of Australia, GPO Box 3947, Sydney, NSW, 2001, Australia. E-mail: simonj@,rba.gov.au I would like to thank Phil Lowe and John Veale for helpful comments. The views expressed in this paper are those of the author and not necessarily those of the Reserve Bank of Australia.
} 
regulation. It argues that the reforms have promoted competition and efficiency in the Australian payment system. A short section concludes.

\section{Payment systems are different}

There are a number of interrelated respects in which payment systems are different from normal markets.

First, payment systems are two-sided markets reflecting the need for joint supply and joint demand. This joint supply requires cooperation among potential competitors within a payment system. In most other markets, competitors do not need to cooperate. Second, the market for payment services is such that unfettered competition between payment systems can lead to distorted price signals to consumers and socially inefficient outcomes. In contrast, in most other markets competition tends to lower, not increase, prices and competition generally delivers efficient price signals. Third, in payment systems the bargaining power between the various parties can be quite unequal. This, combined with low merchant resistance to accepting card payments, means there is often little competitive discipline on payment systems with higher interchange fees. Typically, in most other markets, the bargaining power is more evenly balanced.

\subsection{Coordination within a system can help promote efficiency}

Payment systems involve joint supply. Because of this there has to be some coordination between the issuing bank and the acquiring bank. At the very least, banks must coordinate on technical and procedural standards for exchanging payment instructions. In addition, to establish a payment system or to enhance its efficiency, fees may need to be paid between the various participants. For example, in credit card systems, costs fall predominantly on issuers, while revenues often accrue predominantly to acquirers. ${ }^{1}$ As a result, it may not be possible to profitably offer credit card services absent a payment to issuers.

Notwithstanding the potentially useful role of such cooperation and fees, the possibility for anticompetitive conduct to arise from such cooperation is well recognised in existing antitrust laws and economic analysis. This is reflected in the preference for bilateral contractual arrangements, rather than centralised arrangements, that is often enshrined in antitrust laws and common in discussion of payment systems. ${ }^{2}$ The Australian experience with its domestic debit card system, however, suggests that the pro-competitive effects of bilateral arrangements can be overstated and that there are a number of drawbacks to bilateral arrangements. $^{3}$

First, such arrangements can make it difficult for new entrants to join the system; incumbents can simply decline to enter into contracts with potential entrants. And because potential entrants are also potential competitors, the incentives to do this could be strong. In contrast to the incentives of individual scheme members in a bilateral system, centralised scheme administrators tend to promote entry to their systems. For example, Visa, MasterCard and, more recently, American Express actively seek to expand the number of institutions

\footnotetext{
${ }^{1}$ See RBA and ACCC (2000), chapter 5 for a detailed accounting of costs and revenues in the Australian credit card schemes.

${ }^{2}$ See, for example, Baxter (1983) for an early consideration of this issue.

${ }^{3}$ Discussions of the costs and benefits of bilateral systems are, for the most part, theoretical because there are remarkably few payment systems in the world that are organised on that basis. Australia's domestic debit card system, however, is organised on a bilateral basis and, thus, provides a useful example of how bilateral systems operate in practice.
} 
participating in their networks. ${ }^{4}$ At a technological level, one advantage of a centralised architecture is that it is easily scalable whereas bilateral arrangements become increasingly cumbersome as the number of participants grows. The most obvious example is that telephone networks do not involve bilateral links between all subscribers but operate through telephone exchanges on a hub and spokes architecture. Thus, the limited scalability of bilateral architectures can further limit competition by creating a significant technological barrier to access.

Second, interchange fees in bilateral systems appear to be subject to very limited competition. In Australia's EFTPOS system interchange fees, which are negotiated bilaterally, have remained broadly unchanged for many years despite significant changes in costs, revenues and transaction volumes on both the issuing and acquiring sides of the market. ${ }^{5}$ Issuers and acquirers alike have little incentive, or ability, to instigate competition over the interchange fee because of a form of gridlock.

This gridlock stems from the fact that both issuers and acquirers enjoy monopsony power. Consumers often prefer to maintain one transactional banking account. This provides their bank with the exclusive ability to complete electronic transactions involving that customer no other bank can provide that service. An acquirer cannot demand a higher fee from an issuer because they do not have a meaningful threat if the offer is refused. The merchants they service wish to be able to accept cards from all customers - regardless of where they bank - and, thus, they can not credibly threaten to end an interchange agreement with an issuer if they refuse to pay a higher interchange fee. The reverse is also true. In any negotiation with an acquirer over the interchange fee, an issuer cannot credibly threaten to end the current agreement if a lower fee is not agreed. Ending the agreement would mean that the issuer's cardholders were not able to use their cards at merchants serviced by that acquirer. Issuers have found this to be commercially untenable as it means they can not offer a full-service transaction account which directly harms their competitive position. Thus, both issuers and acquirers have hold-up power over any negotiations. This simultaneous hold-up power means that, once established, it is difficult for interchange fees in a bilateral system to be reset as economic circumstances change.

This interchange fee gridlock that can emerge in bilateral systems can be overcome by a central administrator. In principle, such an approach can also offer the prospect of achieving economically efficient interchange fees - something which is unlikely to be achieved with bilateral arrangements except by chance.

Thus, unlike most normal markets, there are significant benefits in terms of both competition and efficiency that can be gained through a payment system operating on a centralised basis, with cooperation among the various parties and the central setting of interchange fees.

\subsection{Competition between payment systems is distorted}

Despite the potential benefits of cooperation, there is no guarantee that any cooperation will deliver the socially optimal outcome. Indeed, when competition between payment systems or schemes occurs the experience has not always been a favourable one. ${ }^{6}$ The clearest example

\footnotetext{
${ }^{4}$ See http://www10.americanexpress.com/sif/cda/page/0,1641,2553,00.asp for an explanation of the American Express Global Network Services program whereby American Express allows certain banks to issue its cards.

${ }^{5}$ RBA (2005, p.20).

${ }^{6}$ See, for example, the theoretical model of Guthrie and Wright (2003) for some insight into this behaviour. "..when consumers only choose to hold one card [Visa or MasterCard], competition between card schemes does not result in lower interchange fees. In this case, by attracting cardholders, card schemes have a monopoly over
} 
of this is perhaps seen in the changes in interchange fees in US credit and debit card schemes over the past decade where competition between Visa and MasterCard has perversely pushed fees up, not down (Graph 1). The result has been higher average merchant service fees.

The increase in scheme-based debit interchange fees which occurred in 1999 was initiated in 1998 when Visa announced an increase in its fees for 1999. MasterCard responded by announcing an increase in its fees. Visa responded to MasterCard's response by announcing a further increase in its fees. And MasterCard responded to Visa's response to MasterCard's response to Visa's initial increase by announcing another increase in its fees. All before any fees were actually increased. ${ }^{7}$ More generally, scheme-based debit cards have higher interchange fees than PIN-based debit cards which had been associated with increasing market share for the scheme based debit cards until the PIN-based schemes reacted by raising their own interchange fees. ${ }^{8}$ The competitive process here would seem to be driving interchange fees up as schemes compete for market share by raising interchange fees. ${ }^{9}$

While some consumers might benefit from receiving higher rewards or better benefits as a result of increasing interchange fees, economic efficiency can be impaired just as much by excessive subsidies as by excessive taxes. And all consumers, not just credit card users, ultimately pay for the rewards through higher prices for goods purchased at merchants because of restrictions placed on merchants by the schemes. Thus, "competition" in the credit card market is driving subsidies to cardholders (via their banks) higher and higher while the merchants, who support the subsidies, are charging all consumers more as a result.

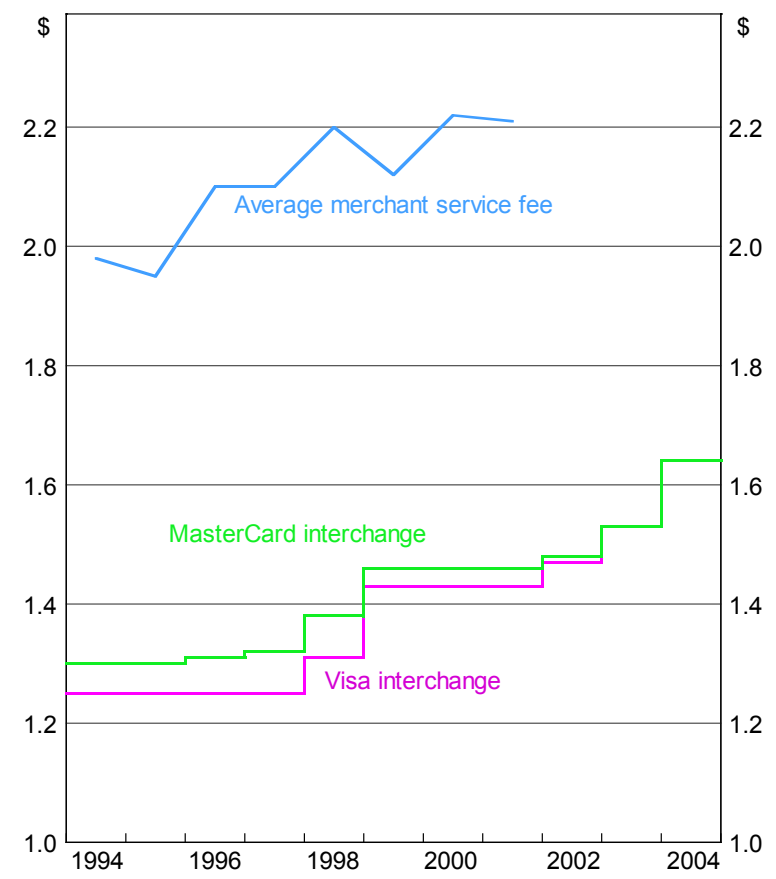

\section{Graph 1: US credit card fees (per $\$ 100$ transaction)}

Sources: MasterCard, Visa

\footnotetext{
access to these cardholders. This leads competing card schemes to care only about the surplus they can offer to cardholders, leaving no surplus to merchants (the case of a competitive bottleneck).” (p.2)

${ }^{7}$ See Balto (2000).

${ }^{8}$ See Constantine (2005) for a more detailed account of the behaviour of both scheme and PIN debit systems in the US.

${ }^{9}$ Scheme-based fees fell in 2003 because of the settlement of a large antitrust case against Visa and MasterCard.
} 
A similar process is evident in the debit card market (Graph 2).

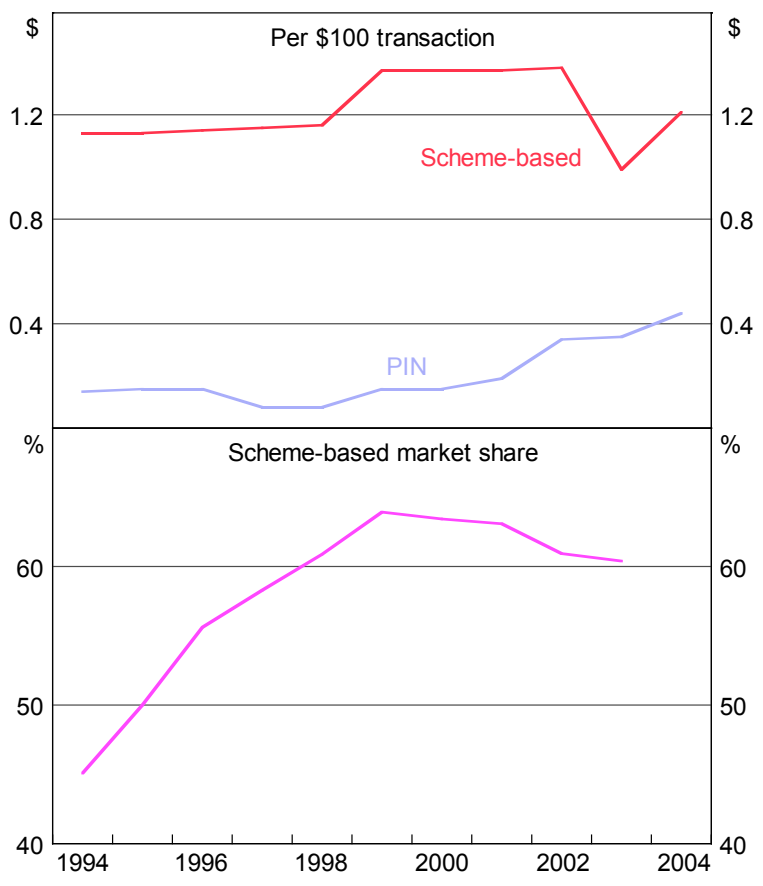

\section{Graph 2: US debit card interchange fees and market shares}

Sources: MasterCard; Nilson report; Visa

Furthermore, these subsidies are affecting consumer choices about which payment system to use (for example debit or credit), not just which scheme to use within a payment system (for example MasterCard or Visa). It is these choices in particular that can have significant consequences for economic efficiency. It is difficult to see significant differences in the functionality offered by a credit card and a debit card used at the point of sale. Yet consumers have shown an increasing preference to use credit cards for these transactions, driven, in part, by the large subsidies for use they receive. When contrasted with the fact that debit cards are a less resource intensive way of performing the same transaction, there are strong grounds to conclude that price signals to consumers are driving inefficient choices about which payment system to use. ${ }^{10}$ These price signals are driven by interchange fees. In normal markets, prices would be driven towards costs and efficient usage decisions would result. In card payment systems, prices to consumers are driven away from costs and inefficient usage decisions result.

\subsection{Merchants have low resistance}

In normal markets, an increase in prices would usually result in a reduction in demand. This, however, does not always apply in payment systems. In particular, merchant acceptance of credit cards seems to be relatively invariant to merchant service fees.

One reason that merchants have low resistance to higher merchant service fees is that the value of the underlying transaction is generally significantly more than the cost of the payment method. Furthermore, a merchant does not know when a customer proffers a credit

\footnotetext{
${ }^{10}$ RBA and ACCC (2000, chapters 5 and 6).
} 
card whether they will still be willing to purchase the goods from that merchant if the merchant refuses the card. Thus, a store will accept credit cards because of the risk that it will loose the underlying sale, which is of much greater value to it than any saving it might make by diverting the customer to a cheaper form of payment.

Another reason for this low resistance is that merchants are caught in a situation akin to the prisoner's dilemma. ${ }^{11}$ In competitive markets a significant reason for merchants to accept credit cards is not necessarily because doing so offers cost savings to the merchant, but, rather, by accepting a credit card they can attract customers from other stores. ${ }^{12}$ In turn, customers are often attracted to stores accepting credit cards, not necessarily because the credit card offers greater inherent convenience than a debit card, but because of the relatively high subsidies offered to them when they use their credit cards. The prisoner's dilemma arises because all merchants face this same decision and, thus, in equilibrium, most accept credit cards, but have no more customers and higher costs.

An example of the prisoner's dilemma can be seen in grocery retailing in Australia. There are two major supermarket chains in Australia, Woolworths and Coles. Neither accepted American Express until the mid 1990s when Woolworths began accepting their cards. Coles quickly followed suit. In the end, their competitive positions would seem to be largely unchanged but they are now paying higher merchant service fees.

This low resistance of merchants is linked with the imposition of restrictive rules on merchants that limit the ability of the price mechanism to fulfil its usual efficiency enhancing role. In many countries, scheme rules prohibit merchants from charging extra to accept a credit or charge card or offering a discount for cash. Some card schemes also enforce rules that prohibit a merchant from even expressing a preference for one card over another. Further, card schemes also exercise their bargaining power over merchants by offering a take-it-or-leave-it proposition where merchants must accept all products issued by the scheme or none. This tying was recently the subject of litigation in the US. And, despite the multitude of acquirers, centralised setting of interchange fees places a floor under merchant service fees such that the competition between acquirers cannot drive prices any lower than the interchange fee.

\subsection{The need for a regulatory response}

The distinctive features of payment systems have tended to create a situation where economic efficiency is not necessarily being promoted. ${ }^{13}$ In the case of Australia, work done by the Reserve Bank of Australia (RBA) has demonstrated that the relative prices for different payment instruments are significantly out of line with relative costs. When the Bank looked at why this was the case it was clear that interchange fees played an important role. Prior to the Bank's reforms in the credit card systems, the average interchange fee was around 0.95 per cent of the transaction value, paid to the issuer (the fee was the same for signature-based debit cards). In contrast, in the PIN-based debit card system the interchange fee flowed in the opposite direction - that is, from the issuer to the acquirer - and averaged around 20 cents per

\footnotetext{
${ }^{11}$ Such behaviour is easy to demonstrate in the model of Rochet and Tirole (2000). See, in particular, Propositions 1 and 2 and Appendix 2 - “...merchant $i$ 's not taking the card makes merchant $j$ 's less willing to accept it. A consequence of this strategic complementarity between merchants is that multiple equilibria may exist." (p.15)

${ }^{12}$ See, for example, Rochet and Tirole (2000) - "Generically, though, Baxter's model overstates merchant resistance by ignoring that card acceptance is a competitive instrument." (p.15)

${ }^{13}$ Rochet and Tirole (2002) discuss some theoretical aspects of this, "competition between not-for-profit associations need not generate an efficient outcome". (p.22)
} 
transaction. These fees led to the lower cost payment instrument being offered to consumers at the higher price.

Furthermore, the card schemes' so-called no-surcharge rule prohibited merchants from reflecting differences in costs to them in prices charged to customers. The end result was that merchants had little option other than to charge higher prices to all their customers to pay for the relatively large subsidies to credit card users.

Given the similarity of payments systems across countries, such conclusions may also apply elsewhere. An important question is then, how might these problems be addressed by existing regulatory regimes? While Australia has payments system specific regulation, many other countries have antitrust legislation alone. The next section considers these two regulatory regimes and their relative benefits when applied to the payments system.

\section{Two regulatory approaches}

Payment systems have long been accorded special status by governments.

At the most basic, currency issued by a central bank speaks of strict government regulation of the provision and use of cash: it is legal tender and private issuance is prohibited. Central banks are also heavily involved in the operation and regulation of highvalue payment systems for interbank transactions and settlement. Furthermore, central banks have been involved in the prudential regulation of financial institutions that are fundamental to the operation of payment systems.

In contrast to this general experience, little attention has been paid to the regulation of competition or efficiency in retail payment systems. In most countries, the main entity responsible for competition in retail payment systems is the antitrust authority. Thus, for example, the Office of Fair Trading in the UK has been investigating MasterCard over the setting of its interchange fees since 2000. In Europe, the EU Commission investigated the credit card companies over cross border interchange fees. And the Department of Justice in the US has recently concluded a case against Visa and MasterCard over restrictions on their members issuing American Express products (among others).

There is, however, an alternative to using the generalist antitrust authority to regulate payment systems. It is to have a specialist payment system regulator. Using a specialist regulator is a relatively common approach in industries that are sufficiently different from normal markets that generic regulation is insufficient. Thus, for example, natural monopolies are commonly subject to specific regulation by a specialist regulator. And, as has been argued above, payment systems are different from normal markets.

These two approaches can have some important differences in practice and, consequently, can lead to different outcomes. The remainder of this section discusses this in more detail.

\subsection{Characteristics of antitrust regulation}

Antitrust legislation generally enumerates specific acts that are illegal (that is per se illegal acts). These acts are generally those that are considered so clearly anticompetitive that no further enquiry as to the competitive consequences of the acts is deemed necessary. ${ }^{14}$ Where the antitrust authority can prove in a court that the per se illegal acts occurred, a conviction

\footnotetext{
${ }^{14}$ Justice Scalia writing in dissent on the Kodak vs ITS Supreme Court judgement expressed it thus: "Per se rules of antitrust illegality are reserved for those situations where logic and experience show that the risk of injury to competition from the defendant's behavior is so pronounced that it is needless and wasteful to conduct the usual judicial inquiry into the balance between the behavior's procompetitive benefits and its anticompetitive costs."
} 
can be secured and the conduct stopped. One example is that contracts between competitors that control or maintain prices are per se illegal in Australia. ${ }^{15}$ Similar prohibitions exist around the world.

The validity of legislative conclusions about the effects on competition of per se illegal acts has been the subject of heated debate. For example, US antitrust laws contain a per se prohibition on tying. The basis for this prohibition has been both questioned and defended by numerous writers, ${ }^{16}$ and the legal interpretation of these rules has also varied over time. ${ }^{17}$ This serves to highlight that what is determinative is the legislation and precedent, not necessarily the economics - with per se rules there is no enquiry into the merits of the case.

Antitrust legislation also generally contains provisions that make reference to more general tests related to competition or the public benefit. In Australia the tests commonly applied are whether something will lead to a "substantial lessening of competition" or whether an activity will provide for a "net public benefit". In the US the equivalent is the "rule of reason". With these provisions, in contrast to per se restrictions, the competition authority (or the party that is challenging the conduct) must prove to a court's satisfaction that it is harmful. ${ }^{18}$

Where breaches can be established, the nature of remedies that can be crafted by antitrust authorities can also be constrained. In this respect, an important feature of the operation of antitrust legislation in Australia (the Trade Practices Act or TPA) is the possibility for "authorisation" of conduct that might otherwise breach the legislation. Under these arrangements companies that wish to enter into arrangements that might breach the TPA can submit an application for authorisation to the antitrust authority (the Australian Competition and Consumer Commission or ACCC). The ACCC assesses the application to determine if the proposed conduct results in a net public benefit. If the ACCC authorises the arrangement the companies are protected against prosecution under the TPA for that conduct. Absent rejection, however, the ACCC can not require that a proposal be reworked to provide for a larger public benefit. An implication of this is that companies may have an incentive to do "just enough" to meet the net public benefit test.

\subsection{Specialist payments system regulation}

In Australia the Reserve Bank of Australia is specifically charged with promoting competition and efficiency in the payments system. The Reserve Bank regulates the Australian payments system under the Payment Systems (Regulation) Act (PSRA) $1998^{19}$ and the Bank's payments system policy is determined by the Payments System Board (PSB).

Under the Payment Systems (Regulation) Act the Bank has the power to:

- "designate" a particular payment system as being subject to its regulation. Designation by itself has no particular effect; it is simply the first of a number of steps the Bank must take to exercise its other powers;

- determine an access regime including rules for participation in that system;

\footnotetext{
${ }^{15}$ Section 45A of the TPA deals with "contracts, arrangements or understandings in relation to prices". See http://scaleplus.law.gov.au/html/pasteact/0/115/0/PA002290.htm for a copy.

${ }^{16}$ See, for example, Whinston (1990) and Posner (1976).

${ }^{17}$ Hylton and Salinger (2001) provide a summary of the history of legal interpretation of the tying rule while also arguing against the per se prohibition on tying.

${ }^{18}$ In the Australian case this is absent authorisation, which is discussed in the next paragraph.

${ }^{19}$ A copy of this legislation can be found at: http://scaleplus.law.gov.au/html/pasteact/2/3141/top.htm
} 
- $\quad$ set standards to apply to participants in the system;

- $\quad$ direct participants in a designated payment system to comply with a standard or access regime; and

- $\quad$ arbitrate on disputes in that system over matters relating to access, financial safety, competitiveness and systemic risk, if the parties concerned agree to arbitration.

The Act also gives the RBA extensive powers to gather information from a payment system or from individual participants.

The powers to designate, to set standards or impose an access regime are subject to the requirement that the PSB must form the opinion that to do so would be in the public interest. In forming this opinion the Reserve Bank must:

...have regard to the desirability of payment systems:

(a) being (in its opinion):

(i) financially safe for use by participants; and

(ii) efficient; and

(iii) competitive; and

(b) not (in its opinion) materially causing or contributing to increased risk to the financial system.

The Reserve Bank may have regard to other matters that it considers are relevant, but is not required to do so. ${ }^{20}$

The Bank is also required to consult extensively before it implements any reforms.

The actions of the Reserve Bank are subject to, and have been subjected to, judicial review. ${ }^{21}$ The nature of that review is that the process leading to the decision is reviewed rather than the decision itself. ${ }^{22}$ This means that, for the most part, provided the Bank follows the correct process, it is able to act in a wide range of circumstances, not just when it identifies breaches of competition law.

\subsection{Alternative regulatory regimes and payment systems}

These two regulatory regimes are ostensibly aimed at the same objective - the promotion of public welfare. However, they seek to achieve this in different ways. These differences have implications for the actions that might be taken by the regulators and the outcomes that could result.

The largest difference between antitrust regulation and a specialist regulator (as implemented in Australia) is the flexibility of the regulators. The antitrust legislative framework is such that, regardless of whether or not a certain activity is per se illegal, there needs to be a (perceived) breach of some existing rule to trigger action. Thus, antitrust enforcement is generally reactive rather than forward looking. It is very difficult for it to address emerging or potential problems until some law is breached - courts have a hard time dealing with what someone may do rather than what someone has already done. And activities that are harmful, but not mentioned in legislation, can not be prosecuted or, at the least, can only be prosecuted with great difficulty.

This lack of flexibility becomes most apparent when dealing with markets that differ substantially from normal markets. Antitrust legislation and its case law precedent are, on the whole, centred on the notion of traditional one-sided markets without significant structural

\footnotetext{
${ }^{20}$ Payments System (Regulation) Act 1998, Section 8.

${ }^{21}$ See, for example, Tamberlin (2003).

${ }^{22}$ Tamberlin (2003, p.8-12) provides a summary of the nature of judicial review with respect to the PSRA.
} 
complications. Thus, the practices which are deemed illegal are typically those that have deleterious consequences in traditional one-sided markets. Where markets are different, existing rules, and particularly per se rules, could lead to anomalous outcomes.

One expression of this difference in flexibility is that the Payments System (Regulation) Act is focused on objectives rather than processes. As such, it does not contain per se restrictions on conduct. Rather, conduct is evaluated by reference to overriding principles of competition, efficiency and financial stability. In dealing with anti-competitive acts or inefficiency, the Reserve Bank can implement standards or an access regime if it believes it is in the public interest to do so. Thus, the regulator can adopt a forward looking approach and has wide discretion over the remedy crafted. For example, the Bank can seek solutions that involve larger gains in social welfare than would be the case if it was limited to merely ensuring that the net social benefit of participants' actions was positive.

Antitrust legislation, for example, contains a strong presumption that agreements about prices between competitors are anticompetitive. This traditional distrust of coordinated price setting is demonstrated in the case of the Australian EFTPOS system (the main domestic debit card system). A group of banks put a proposal to the ACCC for authorisation of an agreement to move interchange fees from an average of minus twenty cents (that is twenty cents paid from issuer to acquirer) to zero. This agreement was supported by the Reserve Bank as being in the public interest because it would have promoted more efficient pricing of EFTPOS services to consumers vis a vis competing payment systems. While the ACCC authorised the conduct, on appeal by a group of retailers, authorisation was denied by the Australian Competition Tribunal. The Tribunal found that "We see little public benefit in allowing this change to come about by the means of a per se unlawful agreement". 23

Under typical antitrust regulation, once the coordinated setting of fees has been authorised or passed through antitrust litigation, there is apparently little scope to limit the results of that process. Subsequent to the Nabanco case in the US and until very recently, there had been no antitrust action directed at the setting of interchange fees. And this was in a market where interchange fees rose significantly. Even assuming that the recently filed actions are successful, the effective regulation of interchange fees would seem to be very difficult to achieve within the antitrust context. The possibility that a privately beneficial settlement between the credit card schemes and the litigants occurs can not be ruled out, and any such privately beneficial settlement is unlikely to be socially optimal.

Recognising the special nature of payment systems, the Reserve Bank of Australia has acknowledged that centralised setting of interchange fees has the potential to be efficiency enhancing. Notwithstanding this, the Bank has taken the position that the level of fee decided upon by schemes is not necessarily in the public interest and may need to be regulated.

Finally, it is unclear how antitrust regulators could address the unequal bargaining power and limited merchant resistance that exists in the payments system. For example, standard market evaluation procedures would not necessarily indicate that there is anything wrong with the merchant/acquirer interaction. There are typically a large number of acquirers offering services to merchants - thus, market definition approaches looking at this market would not lead to any conclusion that monopoly power was an issue. Furthermore, although merchants face significant commercial pressures to accept credit cards, they are not legally bound to accept credit cards. Thus, courts may have difficulty recognising the inefficiency inherent in the nature of this market. In contrast, as is outlined in section 4, the RBA has instituted a number of changes to the restrictions placed on merchants by card schemes.

${ }^{23}$ ACT (2004, p.157). 


\subsection{Summary}

This discussion illustrates how the two sets of legislation, although ostensibly concerned with the same objective, can be different in practice. An important factor is that antitrust legislation is primarily concerned with process, whereas the Australian payments system legislation is focused on objectives. This difference gives the Australian payment system specific approach greater flexibility in considering regulatory solutions to market inefficiency. This is somewhat analogous to the difference between monetary policy run through intermediate targets or run directly with inflation targeting. Traditional antitrust legislation defines the intermediate targets, which, under normal circumstances, have a relationship with efficiency, and those targets are then pursued. However, in unusual situations those intermediate targets may not be a good means of achieving efficient outcomes. Just as monetary targeting did not deal well with changes in the nature of money demand, traditional antitrust legislation can have difficulties when applied to payment systems.

\section{$4 \quad$ Regulation in Australia to promote efficiency}

The preceding discussion has been relatively abstract. The next section considers the outcomes of the regulatory process in Australia. It starts with background information on the Australian market and the history preceding the regulatory reforms.

\subsection{Australian card payment systems}

Card payment systems in Australia are similar to those in many other countries. There are three credit card schemes - Visa, MasterCard and Bankcard. Bankcard is a domestic credit card scheme that was introduced in 1974 before either MasterCard or Visa established operations in the country; in recent years it has been in decline and currently has a single digit market share. As is standard practice for credit card systems, interchange fees based on the transaction value flow from acquirers to issuers. MasterCard and Visa imposed "no surcharge" rules that prohibited merchants from adding an extra charge for paying by credit. And all the schemes had access restrictions that limited membership to deposit takers and placed penalties on organisations that concentrated on acquiring instead of issuing.

Both Diners Club and American Express also operate card payment systems in Australia. Diners Club is exclusively a charge card provider but American Express, in common with its practices in other parts of the world, offers both credit and charge cards. As three-party systems there are no interchange fees as such. Notwithstanding this, American Express has recently entered into partnerships with two domestic banks where the banks issue American Express cards and receive a payment from American Express. In contrast to the four-party schemes, these fees are not centrally determined but are subject to negotiation between American Express and the bank issuers.

Australia also has two debit card systems. The first is the Visa branded debit card system which is similar to the debit card system operated by Visa in many other markets. Interchange fees for this system are identical to those for Visa credit cards. For historical reasons, this product is primarily issued by small financial institutions such as building societies and credit unions. There is also a domestic PIN-based debit card system called EFTPOS (electronic funds transfer at point of sale). This system is organised quite differently to most card payment systems and operates through a series of bilateral links between banks rather than through a central scheme administrator. There are nine direct participants in this network. Smaller financial institutions participate by making use of gateway arrangements 
with the direct participants. In the EFTPOS system interchange fees are negotiated bilaterally and flow from issuers to acquirers. Notwithstanding the bilateral negotiation, most agreements are very similar and the average interchange fee is around a flat 20 cents per transaction. The EFTPOS system is around six to seven times larger than the Visa Debit system.

\subsection{Historical context}

When the Payments System Board was established one of its first actions was to review the operation of debit and credit card schemes in Australia. The results of this investigation were published in October 2000 as Debit and Credit Card Schemes in Australia: A Study of Interchange Fees and Access, commonly referred to as the Joint Study.

The main focus was on assessing the relative costs for transactions on credit and debit cards and examining how interchange fees in the systems affected the prices users faced. The Joint Study found that the PIN-based debit card system had significantly lower operating costs than either the Visa Debit system or the credit card systems. Despite this, cardholders faced much higher prices for using the EFTPOS system. At the time of the study, it was not uncommon for transactions using a PIN-based debit card to attract a fee of around 40 to 50 cents. In contrast, transactions using the signature-based system were not charged, while many holders of credit cards were effectively paid each time they used their card as a result of the combination of interest-free credit and reward points. Not surprisingly, consumers responded to these price signals.

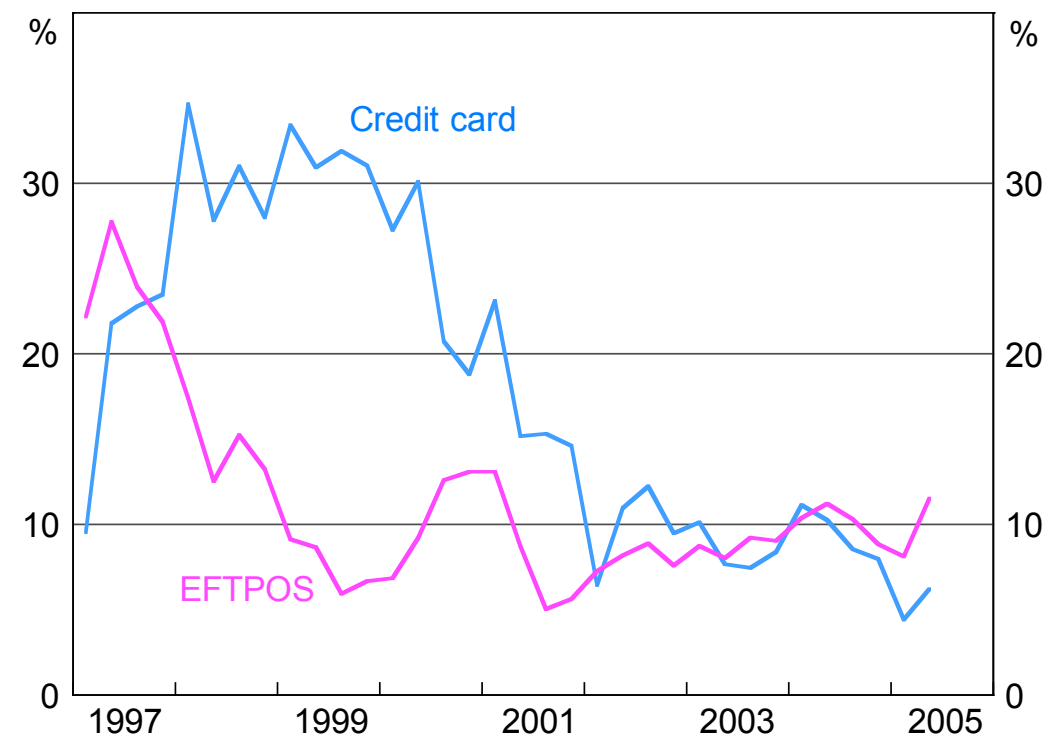

\section{Graph 3: Growth in the value of credit and debit card transactions}

Spending on credit cards grew by around 20 to 30 per cent per annum over the second half of the 1990s, while spending on PIN-based debit cards grew at an average rate of around 10 per cent per annum.

As mentioned above, when the Bank looked at why the relative prices were so far out of line with relative resource costs it was clear that interchange fees played an important role.

As a result of that study, the Bank came to the view that the efficiency of the overall system was being impaired by cardholders facing relative prices for various payments methods that did not reflect the relative costs. The Bank also formed the view that existing 
access arrangements and restrictions on merchant pricing imposed by the card schemes (the no surcharge rules) were limiting competition.

\subsubsection{ACCC action against the NAB}

Prior to the Joint Study being conducted the ACCC had received a complaint about the setting of merchant service fees in Australia. It was investigating this complaint at the time the Joint Study was being conducted, with the investigation being kept entirely separate from the conduct of the Joint Study. The ACCC came to the view that the collective setting of interchange fees breached the Trade Practices Act in Australia and invited the scheme participants to submit an application for authorisation to the ACCC. In September 2000, when it became clear that an application was not likely to be submitted, the ACCC instigated antitrust action against a large bank (the National Australia Bank). It alleged that the setting of interchange fees in the credit card schemes had the effect of maintaining or supporting merchant service fees, which was illegal. This action proceeded relatively slowly and was still in its preliminary stages when the Bank designated the credit card schemes in Australia in April 2001. Following that action the ACCC dropped its action against the NAB as it believed that the use of the RBA's powers would be a better way to achieve reform of the credit card schemes.

\subsection{Credit card reforms}

The first exercise of the Bank's powers was in April 2001 when it designated the three credit card schemes operating in Australia. Following extensive consultation it issued draft standards and a draft access regime in December 2001. These drafts were subject to consultation and changed through that process. Final standards were imposed in August 2002 and an access regime in February 2004.

The standard on merchant pricing prohibits so called "no surcharge" rules in the credit card schemes. The standard on interchange fees requires that the fees be below a specified benchmark. At the same time, the three-party schemes in Australia voluntarily agreed to remove their "no surcharge" restrictions. Finally, the access regime requires the credit card schemes to relax their membership requirements in Australia to allow specialist credit card institutions to join the schemes and prohibits penalties or loadings on predominantly acquiring institutions (as had previously been in place).

\subsubsection{Interchange fee regulation}

The standard on interchange fees requires the weighted average of interchange fees in the credit card schemes to be under a level set by reference to specified issuing costs. These costs include the cost of processing and authorising a transaction, the cost of funding the interestfree period and the cost of fraud and fraud related expenses. The cost-based approach was not adopted because it had particular theoretical merit but, rather, because it was a pragmatic and transparent way of addressing the distortions in relative prices that had been identified in the Joint Study. It was also chosen because it met the legal test of being a "standard" under Australian law and there were some questions as to whether the Bank had the power to simply set a price for the interchange fee.

It had been argued that, in the face of Reserve Bank actions on surcharging and access, regulation of interchange fees was unnecessary. The problem with this position is that, as argued above, card payment systems, left to their own devices, do not tend towards efficient operation. While in normal markets increased access could be expected to cure many anticompetitive ills, this was not the case in the credit card market. The structural features of the market are such that increased access to issuing or acquiring would not, of itself, overcome the problems with the inefficient setting of interchange fees: large subsidies to 
consumers that distort payment systems choice; relatively high costs to merchants who, in turn, pass those costs on to all consumers; and no effective resistance from merchants to inefficiently high charges.

\subsubsection{No surcharge rules}

The Reserve Bank objected to "no surcharge" rules because they inhibited the normal functioning of the price mechanism. The Reserve Bank required that no participant in the credit card schemes in Australia could impose a restriction on merchant that prevented them from passing on the cost of credit card acceptance to their customers. Furthermore, American Express and Diners Club voluntarily agreed to identical requirements.

Furthermore, the merchant pricing regulations served a dual purpose of not only freeing up the working of the price mechanism but also redressing the imbalance in bargaining power between merchants and acquirers inherent in the system. The power to surcharge does not have to be exercised to be a significant factor in negotiations over merchant service fees merchants may threaten to surcharge and thereby obtain a lower merchant service fee. As such, the observed level of surcharging alone can not be considered an accurate indicator of the effect of the regulation.

\subsubsection{Access restrictions}

The credit card schemes placed various restrictions on membership of their schemes. For the most part, these restrictions required that members be regulated deposit taking institutions. Furthermore, the membership conditions imposed penalties on institutions that specialised in acquiring. The net effect was that competition on the acquiring side of the market was suppressed and issuer views would tend to dominate in any consideration of interchange fees.

The Bank viewed these restrictions as significantly stronger than was required to protect the financial stability of the scheme. Furthermore, the penalties imposed on specialist acquirers were seen as a suppression of competition in acquiring. For this reason, the Bank required the credit card schemes to relax their membership rules to allow a new class of financial institution to participate (Specialist Credit Card Institutions or SCCIs) and to remove penalties on institutions that specialised in either issuing or acquiring. These new institutions are still prudentially supervised and the schemes are free to apply whatever conditions on membership they wish, provided that these conditions do not discriminate against SCCIs in any way.

\subsubsection{Court challenges}

These standards and the access regime were challenged on jurisdictional and procedural grounds by Visa and MasterCard in court. In September 2003 the challenges were dismissed and Visa and MasterCard did not continue with their appeals.

\subsection{Effect of the credit card reforms}

The benchmark for credit card interchange fees came into effect on 1 November 2003. The allowable costs resulted in average interchange fees falling from 0.95 per cent to around 0.55 per cent under the benchmark. The effect on merchant service fees is shown in Graph 4. 


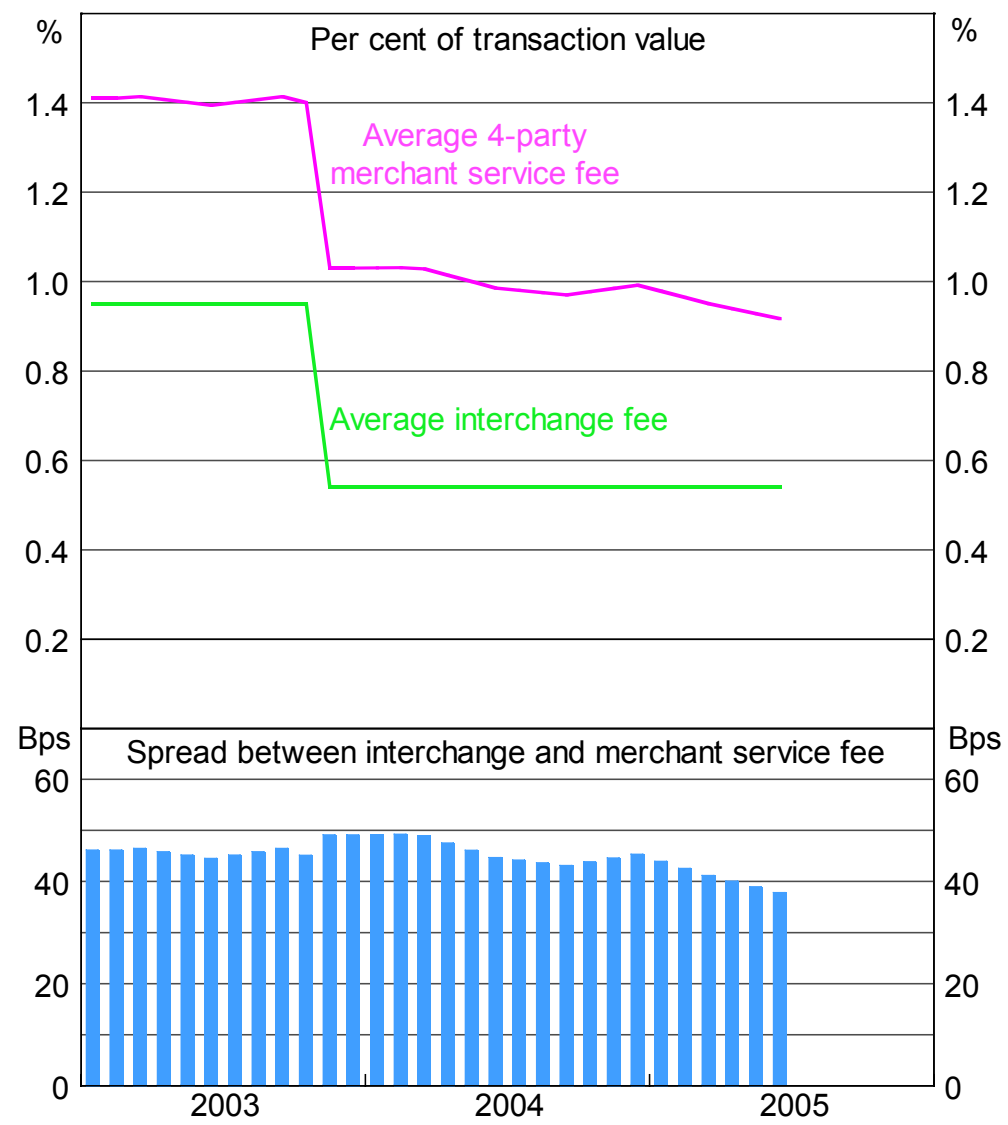

\section{Graph 4: Credit card MSFs and interchange fees}

The average fee in June of this year was 0.92 per cent, down from 1.4 per cent immediately prior to the reforms. The spread between the interchange and merchant service fees has fallen from 45 basis points to under 40 basis points. This suggests that, not only have banks fully passed through to merchants the fall in interchange fees, but the increased transparency and focus on these fees has lead to greater competition among acquirers for merchant business.

In response to the reduction in interchange fee revenue there has also been a scaling back of reward programs, including some capping of reward points, and increases in some annual fees on credit cards. One measure of the changes in reward programs is shown in Table 1. The average reward benefit to cardholders, as a proportion of spending, has fallen by 15 basis points.

\begin{tabular}{lll}
\hline & $\begin{array}{l}\text { Average spending } \\
\text { required for } \$ 100 \\
\text { voucher }(\$)\end{array}$ & $\begin{array}{l}\text { Benefit to cardholder } \\
\text { as a proportion of } \\
\text { spending (b.p.) }\end{array}$ \\
\hline 2003 & 12400 & 81 \\
2004 & 14400 & 69 \\
2005 & 15100 & 66 \\
\hline
\end{tabular}

Table 1: Credit card rewards

Source: Banks' websites. ANZ Telstra/Rewards Visa card, Commonwealth Bank MasterCard Awards card, National Australia Bank Visa Gold card and Westpac Altitude MasterCard. 
In addition to the interchange fee reforms, merchants are now free to pass on the cost of accepting credit and charge cards to their customers if they so desire. A number of private sector surveys indicate that around 5 per cent of merchants are imposing an explicit charge on those who pay with a credit or charge card. ${ }^{24}$ There is also evidence that a number of organisations such as schools, clubs and societies, and government authorities are now accepting payments by credit card with a charge whereas before they did not accept credit cards at all.

Despite the increased incidence of charging, many merchants remain reluctant to charge for credit cards. In part, this reflects the long history over which they were prevented from levying such a charge by restrictions imposed by the credit and charge card schemes. These rules created an expectation among cardholders that they would pay the same price regardless of the payment method chosen. This expectation is now breaking down and, in time, the extent of surcharging is likely to increase. Indeed, a recent survey suggests that around half of all merchants are now thinking about surcharging. ${ }^{25}$

More recently, an access regime has been imposed on the credit card systems that requires the schemes consider applications for membership by SCCIs on the same basis as applications from authorised deposit taking institutions. SCCIs are a special class of prudentially regulated financial institutions. To date two organisations have been authorised by APRA. The first of these, GE Money, involved an essentially administrative change for an already operating company. The second company is, however, a genuinely new entrant and aspiring acquirer. This aspiring acquirer is still in the process of establishing its operations. There are also indications that other companies are considering joining the schemes. The fact that the average merchant service fee has fallen by more than the fall in the interchange fee, and thereby compressed acquiring margins, is certainly an indication that acquiring competition has already increased since the reforms were introduced.

The reforms, particularly the reduction in interchange fee revenue, have also prompted issuing banks to re-examine their product offerings. One result has been a much greater emphasis on products to attract revolvers - that is, those credit card users who normally carry a balance on their credit card and who would benefit more from lower credit card interest rates than from better reward programs. Table 2 shows that the proportion of low-rate products on offer (defined as those with an ongoing rate below 13\%) has grown over the past two years and that eight out of the top ten credit card issuers now offer a low interest rate product. These cards provide a much more attractive proposition for those consumers who regularly use the revolving line of credit.

\begin{tabular}{lllll}
\hline & $\begin{array}{l}\text { Low rate } \\
\text { products }\end{array}$ & $\begin{array}{l}\text { Credit card } \\
\text { products }^{26}\end{array}$ & $\begin{array}{l}\text { Proportion } \\
\text { of low rate } \\
\text { products }\end{array}$ & $\begin{array}{l}\text { Number of top-ten } \\
\text { issuers that offer a } \\
\text { low rate product }\end{array}$ \\
\hline 2003 & 17 & 172 & $9.9 \%$ & 3 \\
2004 & 25 & 198 & $12.6 \%$ & 6 \\
2005 & 35 & 256 & $13.7 \%$ & 8 \\
\hline
\end{tabular}

Table 2: Low-rate products

Source: Cannex

\footnotetext{
${ }^{24}$ East \& Partners (2005).

25 ibid.

${ }^{26}$ Does not include Visa debit products or those credit card products that must be linked to home loans.
} 
For transactors, although the generosity of reward programs has been curtailed, there has also been increased experimentation with alternative reward offerings. For example, instant rewards, where cardholders get discounts for using their card to make a purchase have emerged as well as more targeted loyalty schemes. ${ }^{27}$

\subsubsection{American Express and Diners Club}

While the three-party card companies were not directly affected by the interchange standards it was expected that their merchant service fees would come under competitive pressure. Since November 2003 the average merchant service fee for American Express have fallen by around 15 basis points to 2.36 per cent and the average merchant service fee for Diners Club has fallen by around 5 basis points to 2.31 per cent (Graph 5). Clearly they have not fallen by nearly as much as those for the designated credit card schemes.

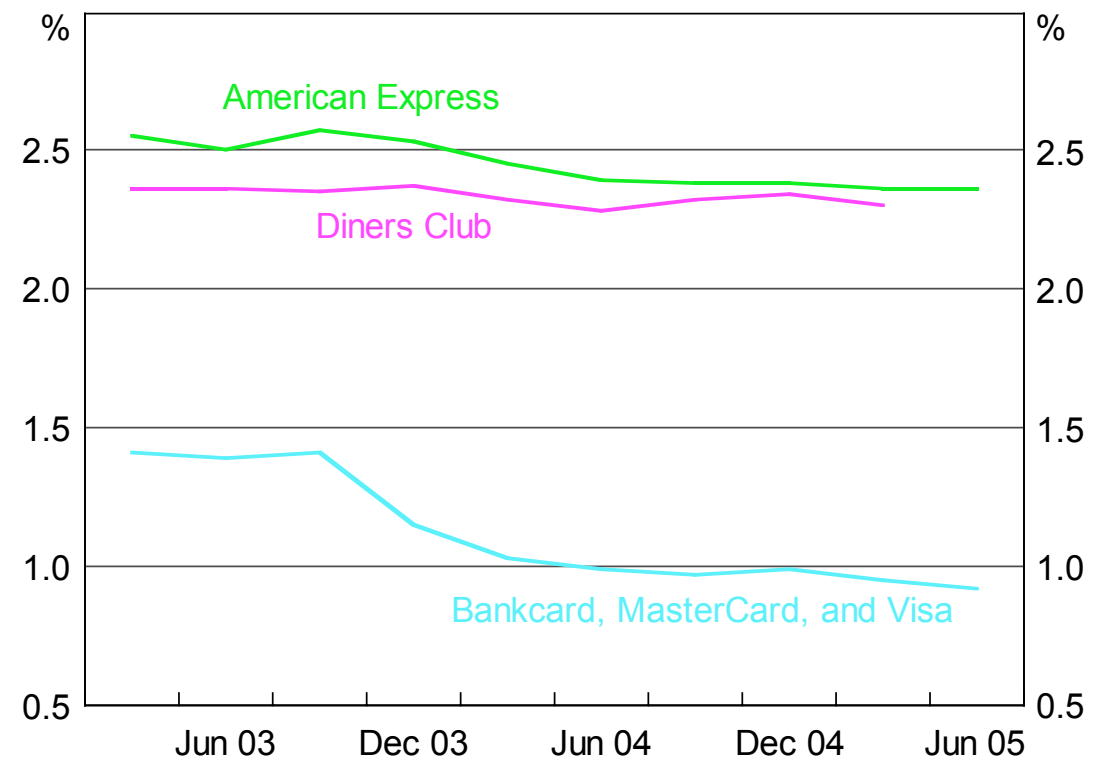

Graph 5: Average merchant service fee (per cent of transaction value)

Over the same time period the market share for American Express and Diners Club has risen by around 2 per cent to 17 per cent (Graph 6). The majority of this rise is associated with the introduction of bank-issued American Express cards in 2004. There are few signs of a broader increase in the market share of American Express and Diners Club.

The Bank has calculated that these changes have resulted in merchants saving approximately $\$ 580$ million over the last year.

Because of the different structure of three-party schemes the Bank has focused attention on the relationship between merchants and the three-party schemes. This has led to changes in the Terms and Conditions of American Express and Diners Club merchant agreements that remove restrictions that prevented merchants from steering customers to use a different card in addition to the earlier changes to the no surcharge rules. The Bank has also increased the information available to merchants through the publication of average merchant service fees

\footnotetext{
${ }^{27}$ Coles supermarkets have an arrangement with Shell service stations whereby people who spend $\$ 30$ or more on groceries get $4 \mathrm{c} /$ litre off their fuel bill. They have added an additional discount for people using their cobranded MasterCard credit card. Visa has recently introduced a similar scheme for people who shop at Woolworth's and use a Visa card.
} 
and market share data presented above. These changes have redressed some of the imbalance in bargaining power between merchants and card schemes.

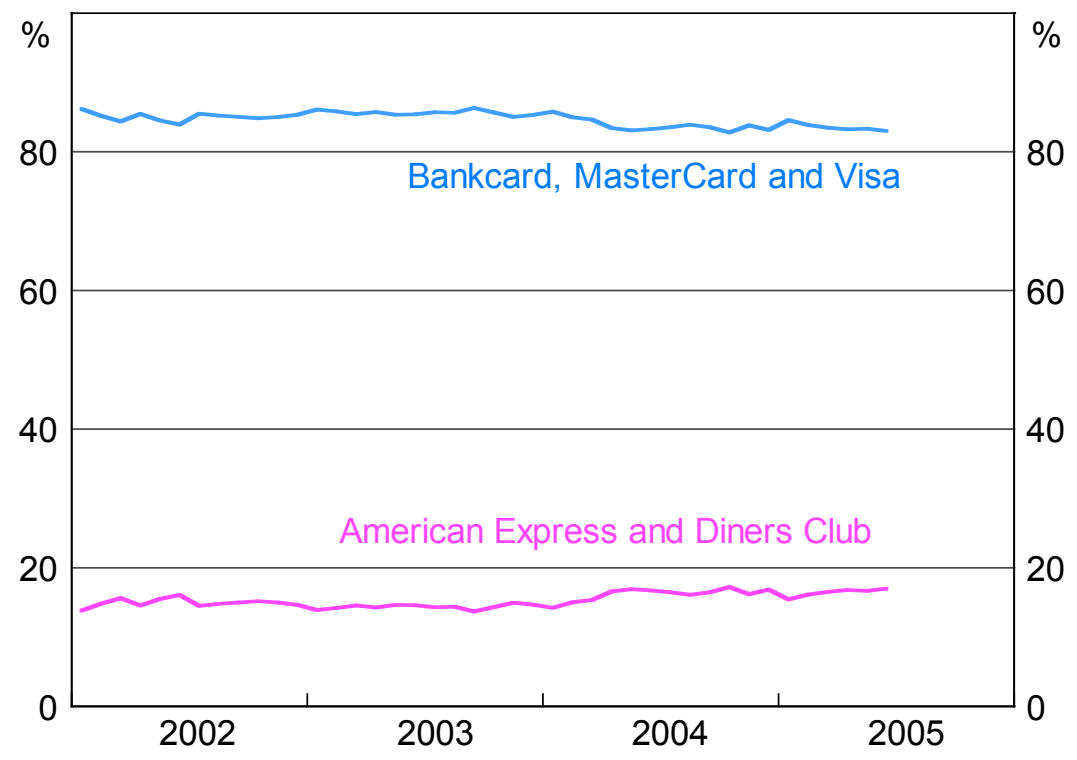

Graph 6: Market share of card schemes (value of purchases)

\subsection{Debit card reforms}

The history of regulatory action with respect to debit cards is somewhat less complete than that for credit cards. It is still ongoing and no regulations have been introduced. While the same issue with respect to credit cards was identified by the Wallis Inquiry and Joint Study, and initial effort in both systems was aimed at voluntary reform on similar timescales, the paths travelled and time taken have turned out quite differently.

Immediately following the Joint Study, there was some discussion of the debit card interchange issue but no steps by participants to initiate reform. Beginning in early 2002, the Reserve Bank convened a series of meetings of industry participants to explore the options for debit card reform. The Reserve Bank's role in these meetings was to facilitate discussion between participants in the industry. The industry group consisted of the largest direct participants in the EFTPOS network, including Coles Myer, a large merchant. Industry views on reform were quite diverse and strongly held; for this reason, the Reserve Bank encouraged the industry group to seek public input into the reform process. In July 2002, the industry group released a paper which outlined three basic options for reform: retention of current arrangements (with small modifications); adoption of collectively determined interchange fees calculated on a cost-based approach; and abolition of interchange fees. Following publication of the paper, the industry group met with interested parties to discuss the options. Significant differences in commercial interests remained both within the industry group and among other interested parties.

Despite the lack of unanimity, in February 2003, an application to the ACCC for authorisation of a proposal to reduce interchange fees to zero was submitted by a group of banks, building societies and credit unions. The proposal was authorised by the ACCC in December 2003, and a group of retailers applied to the Australian Competition Tribunal (ACT) for a review of that decision. The Reserve Bank supported the proposal for zero 
interchange fees before both the ACCC and ACT. The ACT denied authorisation for the proposal in May 2004.

Following the review tribunal's decision the Bank came to the view that if progress was to be made then it would need to be done by the RBA using its regulatory powers. As a result, the Bank designated the EFTPOS system in September 2004 and has released proposals which, if implemented, would likely see the average interchange fee fall from around 20 cents to around 5 cents. The fee would remain payable by issuers to acquirers. The Bank's decision to designate the EFTPOS system was challenged in court by a number of retailers. That challenge was dismissed by the Federal Court in November 2005.

\subsubsection{Access}

An important issue with the EFTPOS system is access. As discussed above, because of the bilateral structure of the system, individual interchange agreements must be negotiated before one institution will accept EFTPOS transactions from any another. One bank alone can effectively "hold up" access for any new participant by delaying the technical connections and the signing of interchange agreements, even when the new entrant is able to meet necessary technical requirements. Thus, achieving access to the system can be extremely complicated and time consuming. Participants in the industry have recently agreed to implement an access regime acceptable to the Reserve Bank that would provide for certainty over the timing and cost for new entrants as well as a clearly defined right of access. Specific details and implementation methods are currently being developed.

\section{Conclusion}

Payment systems are different - they are two-sided, they exhibit network effects and normal competitive forces do not always operate. These characteristics mean that market forces, left to their own devices, may not deliver outcomes that are socially optimal. As a result, there is a case for regulation.

Two broad models of payment system regulation exist - generic antitrust regulation and payments system specific regulation. The Australian example of payments system specific regulation demonstrates some useful benefits. First, by focusing on objectives rather than processes, it avoids some of the problems that a focus on intermediate targets can generate. Second, it allows the regulator to be forward looking rather than reactive. And finally, because the regulator is specialised, it may be better equipped to analyse and understand the complexity of payment systems than is a generalist regulator.

To date, the regulation in Australia has improved price signals to cardholders, improved access, increased competition and given merchants greater ability to negotiate with their acquirers and the schemes. The result is a move towards a more efficient payments system.

\section{$6 \quad$ References}

Australian Competition Tribunal (2004) Re EFTPOS Interchange Fees Agreement 25 May.

Balto D (2000) "The Problem of Interchange Fees: Costs Without Benefits," European Competition Law Review, 215: 215-224.

Baxter W (1983) "Bank Interchange of Transactional Paper: Legal and Economic Perspectives," Journal of Law \& Economics, 26: 541-588. 
Constantine L (2005) "The Need for Federal Reserve and Antitrust Intervention in the Failed US Debit and Credit Card Markets," paper presented at the Conference of Interchange Fees in Credit and Debit Card Industries, Kansas City Federal Reserve Bank, Santa Fe New Mexico, May 4-6.

East \& Partners (2005) Merchant Acquiring \& Cards Markets. August.

Guthrie G and J Wright (2003) "Competing Payment Systems," Working Paper No. 0311, Department of Economics, National University of Singapore.

Hylton K and M Salinger (2001) "Tying Law and Policy: A Decision Theoretic Analysis," Working Paper No. 01-04, Boston University School of Law.

Posner RA (1976) Antitrust Law: An Economic Perspective. University of Chicago Press: Chicago.

Reserve Bank of Australia and Australian Competition and Consumer Commission (2000) Debit and Credit Card Schemes in Australia: A Study of Interchange Fees and Access.

Reserve Bank of Australia (2005) Reform of the EFTPOS and Visa Debit Systems in Australia: A Consultation Document.

Rochet JC and J Tirole (2000) "Cooperation among Competitors: The Economics of Payment Card Associations," paper presented at the Joint CSIO/IDEI Industrial Organization Workshop, Northwestern University, Evanston, IL, April 26-27.

Rochet JC and J Tirole (2002) "Platform Competition in Two-sided Markets," IDEI Working Paper No. 152.

Tamberlin B, (2003) Judgement in Visa International Service Association v Reserve Bank of Australia (N 973 of 2002) and MasterCard International Incorporated v Reserve Bank of Australia (N 987 of 2002), Federal Court of Australia.

Whinston MD (1990) “Tying, Foreclosure, and Exclusion,” American Economic Review, 80: 837-59.

Wright J (2000) “An Economic Analysis of a Card Payment Network,” mimeo. 